\title{
Student Concept Mastery on Coloid Material Through Radec Learning
}

Rukiyahtul Adawiyah Ritonga*, Wahyu Sopandi, Momo Rosbiono

Department of Chemistry Education, Indonesian University of Education, Bandung, 40154, Indonesia.

\section{ARTICLE INFO}

Article history:

Received: 10 Jan 2021

Revised: 29 Juny 2021

Accepted: 03 July 2021

Published online: 24 July 2021

\section{Keywords:}

Concept Mastery

Colloid

RADEC Learning Model

\begin{abstract}
A B S T R A C T
Mastery of concepts is still the main standard of learning success in Indonesia. This study aims to analyze students' conceptual mastery of colloidal material through the RADEC (Read, Answer, Discuss, Explain, and Create) learning model. The research method used is the PreExperiment method with the research design of One Group Pretest-Posttest Design. The number of subjects in this study were 18 students. Data were collected using 25 multiple choice items used for pretest and posttest. Data were analyzed through normality test, $\mathrm{t}$ test and $\mathrm{N}$-gain using SPSS version 21 for windows. The results of the Paired Sample T-Test showed that there was a significant difference between the pretest score (39.7) and posttest score (74.4) $(\mathrm{p}<0.05)$ with the $\mathrm{N}$-gain value obtained was 0.56 . This means that there is an increase in the medium category in students' concept mastery through RADEC learning.
\end{abstract}

\section{Introduction}

Mastery of concepts is a reciprocal relationship between the basic elements in a large structure that function together in its use. These basic elements are facts of knowledge that students must know to be able to solve a particular problem (Krathwohl, 2002). Mastery of concepts is also an effort that must be made by students in recording and transferring back a number of information from a certain subject matter that can be used in solving problems, analyzing, interpreting certain events (Silaban, 2014).

Mastery of important concepts is owned by students. The importance of students mastering a concept according to Suranti et al (2016) is to be able to communicate, classify ideas, ideas or events that they experience in everyday life. Mastery of the concept is essentially an effort to overcome the knowledge gap between students who have high academic achievement and students who are low

\footnotetext{
${ }^{*}$ Corresponding author.

E-mail: rukiyahtuladawiyah12@gmail.com
} 
(Thorndike, 1976; Carrol, 1963; Bloom, 1974). Students who develop mastery of concepts will be faster to do things related to procedural knowledge later than students who memorize and remember only (Nisrina et al, 2016).

Anderson \& Krathwohl (2001) explained the dimensions of knowledge consisting of factual, conceptual, procedural and metacognitive knowledge. Factual knowledge includes knowledge of terminology and elements. While conceptual knowledge includes knowledge of classification \& categories, principles \& generalizations, theories, models and structures. Then procedural knowledge includes (1) knowledge of skills in certain fields and algorithms; (2) knowledge of techniques and methods in a particular field; and (3) knowledge of the criteria for determining when to use appropriate procedures. And metacognitive knowledge includes strategic knowledge, cognitive domain and self-knowledge (Suwarto, 2010).

Anderson \& Krathwohl (2001) classify cognitive domains which are revisions of Bloom's taxonomy in Figure 1:

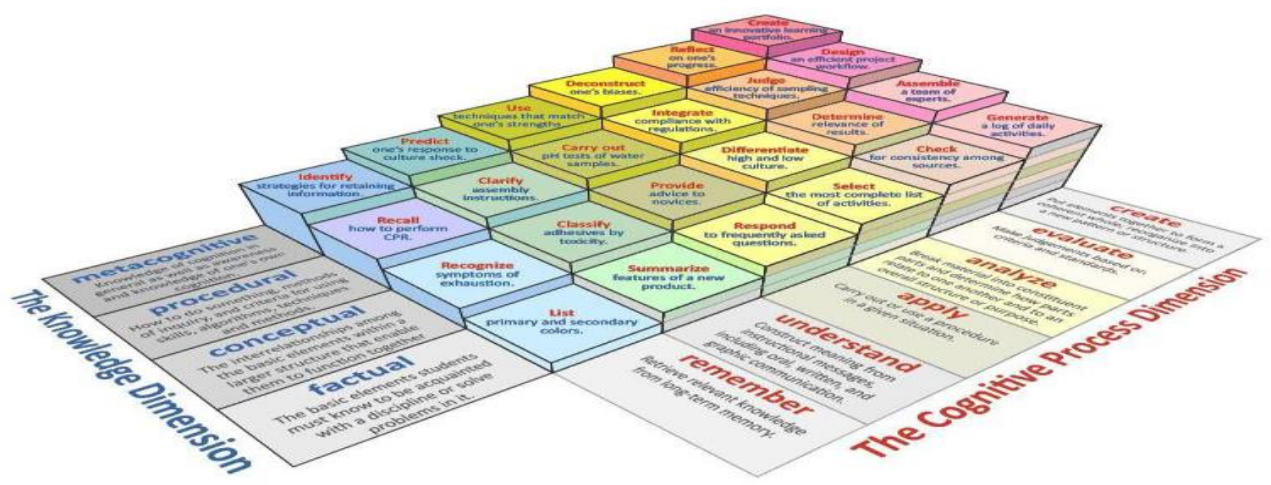

Figure 1. Combinations of the Cognitive Process and Knowledge Dimensions

(Heer, 2012)

The details of the domain are as follows:

1. Remembering, namely the level of ability that requires students to try to regain knowledge from previous memories or memories, whether they have just been obtained or have been obtained for a long time.

2. Understanding, namely the level of ability that requires students to understand or understand the subject matter presented by the teacher and can use it without having to relate it to other things.

3. Applying, namely the level of ability that requires students to use general ideas, procedures or methods, principles, and theories in new and concrete situations.

4. Analyze, namely the level of ability that requires students to describe a certain situation or situation into its constituent elements or components.

5. Evaluate, namely the level of ability that requires students to be able to evaluate a situation, condition, statement or concept based on certain criteria. 
6. Create, namely the level of ability that requires students to produce something new by combining various factors. The results obtained can be in the form of writing, plans or mechanisms.

Mastery of concepts is still the main standard of learning success in Indonesia. This statement is supported by research conducted by Sopandi, Pratama \& Handayani (2019), namely the difficulty of teachers to organize learning in accordance with the demands of the times, they are required to provide alternative solutions by developing a learning model that is appropriate to the Indonesian context.

One of the learning models that has the potential to encourage students to master the learning concepts being studied is the RADEC learning model (Setiawan, 2019). According to Sopandi (2017) the advantages of the RADEC learning model can encourage students to gain a good conceptual understanding of the material being studied. Another advantage of the RADEC model is that the stages of this model are easy for teachers to understand and remember (Setiawan et al., 2020).

This RADEC Learning Model has a positive impact on students through learning steps that encourage students to gain a high understanding (Setiawan et al, 2019) In line with the opinion of Handayani, et al (2019) revealed that learning using the RADEC model learning stages has been proven able to improve students' mastery of concepts. The steps of the RADEC model essentially emphasize students to carry out various activities in learning such as reading, answering, discussing, explaining, and creating works. The syntax of the RADEC learning model is presented in Table 1.

Table 1.The syntax of the RADEC Learning Model

\begin{tabular}{ll}
$\begin{array}{c}\text { Learning Model } \\
\text { Syntax }\end{array}$ & $\begin{array}{c}\text { Steps } \\
\text { RADEC Learning }\end{array}$ \\
\hline Read $(R)$ & $\begin{array}{l}\text { First, students read books and other sources of information related to the } \\
\text { material to be studied. Supporting this activity are learning resources in the } \\
\text { form of textbooks or electronic books. Read (R) step before face-to-face } \\
\text { activities. } \\
\text { Next, students are given pre-learning questions. Questions whose answers } \\
\text { are essential cognitive aspects that must be mastered by students after } \\
\text { completing a particular subject matter. Questions from low order thinking } \\
\text { (LOT) to high order thinking (HOT) skills. Pre-learning questions are } \\
\text { given to students before face-to-face learning in class; }\end{array}$ \\
\hline Answer $(A)$ & $\begin{array}{l}\text { Students answer pre-learning questions. This activity is carried out } \\
\text { independently outside the classroom or at home based on the results of } \\
\text { learning activities in the reading stage; }\end{array}$ \\
\hline Discuss $(D)$ & $\begin{array}{l}\text { Learners study in groups (2-4 people) to discuss answers to pre-learning } \\
\text { questions. At this stage the teacher can identify the various needs of } \\
\text { students; }\end{array}$ \\
\hline Explain $(E)$ & $\begin{array}{l}\text { Presentation of a classical explanation of the material that has been } \\
\text { discussed. Resource persons can be selected from student representatives. } \\
\text { In this case, the teacher acts to ensure that the student's explanation is } \\
\text { correct and that other students can understand the explanation. The }\end{array}$ \\
\hline
\end{tabular}


resource person can also be a teacher but this is only done when it is confirmed that none of the students are able to become resource persons;

Create $(C) \quad$ Students formulate creative ideas in the form of formulation of research questions, problem solving or making works that can be made and make them happen. Creative ideas are in accordance with the material that has been mastered and in accordance with everyday life. The teacher's job is to inspire students to get creative ideas through providing examples of creativity results that are themed with the material that has been studied or providing examples of creative ideas.

Source: Sopandi, W. (2017)

One of the materials studied in high school is colloids. In colloidal learning, most teachers do not hone students' conceptual knowledge because this material is only memorized, so many students experience misconceptions. This can be seen from the research analysis of Latisma, et al (2015) namely the students' conception of the colloid system in terms of rote learning styles, the results tend to be in the category of misconceptions.

Several related studies that are relevant to RADEC learning research on chemistry, namely Vellanda, (2019) in his research entitled "Mastery of chemical equilibrium material through the implementation of the Read-Answer-DiscussExplain-Create (RADEC) learning model". The RADEC learning model can improve the mastery of concepts (average N-gain 48\%, moderate category), meaning that it can improve the quality of the process and learning outcomes of students on chemical equilibrium material. Next is Siregar, (2019) in his research entitled "Design of polymer learning using the Read-Answer-Discuss-ExplainCreate (RADEC) model based on google classroom to develop conceptual mastery and creativity of SMK students in the manufacture of bioplastics. In his research, he discussed that each stage of RADEC was classified as high for the read, answer, explain, create stage and moderate for the discuss stage, while the mastery of students' concepts was classified as high (N-gain 0.73 ) according to the Hake criteria. Furthermore, Ritonga, (2019) in his research on the effect of gender on actual abilities on colloidal material. The results showed that female students had a better actual ability increase than male students.

Based on the explanation above, this study aims to analyze (1) the differences in students' conceptual mastery of colloid material before and after being given treatment using the RADEC learning model; and (2) increasing students' mastery of concepts on colloidal material through the RADEC learning model.

\section{Methodology}

\section{Research Locations and Subjects}

This research was conducted at one of the public high schools in the city of Padangsidimpuan, North Sumatra Province. The sample in this study was 1 class as the experimental class. While the subjects in this study were 18 students of MIA class XI-2. 


\section{Research methods}

The research method used is the Pre-Experiment method with the research design of One Group Pretest-Posttest Design.

Table 2. One Group-Posttest Design.
O-1
$\mathrm{P} \quad \mathrm{O}-2$

(Wiersma \& Jurs, 2009)

Information:

O-1 : Pretest

$\mathrm{P}$ : Treatment of the RADEC learning model

O-2 : Posttest

\section{Research Instruments}

Data were collected using 25 different multiple choice items but still in the same indicator used for pretest and posttest. The pretest was given before learning the RADEC model, while the posttest was given after learning the RADEC model.

The basic competencies of colloid material contained in the 2013 curriculum, namely 3.14 Grouping various types of colloidal systems, and explaining the use of colloids in life based on their properties. In the 25 questions there are 13 indicators that must be achieved, namely:

Table 3. Table of Learning Indicators

\begin{tabular}{|c|c|c|c|}
\hline Concept & Learning Indicators & $\begin{array}{l}\text { Cognitive } \\
\text { Level }\end{array}$ & $\begin{array}{l}\text { Question } \\
\text { Number }\end{array}$ \\
\hline \multirow[t]{7}{*}{ Colloidal System } & $\begin{array}{l}\text { Explain the meaning of dispersion system } \\
\text { (dispersed substance and dispersion medium) }\end{array}$ & $\mathrm{C} 3$ & 1 \\
\hline & $\begin{array}{l}\text { Differentiate the types of dispersion systems } \\
\text { (suspensions, solutions and colloids) based on their } \\
\text { characteristics }\end{array}$ & $\mathrm{C} 4$ & 2 \\
\hline & $\begin{array}{l}\text { Grouping some mixtures into colloids, solutions, } \\
\text { and suspensions }\end{array}$ & $\mathrm{C} 3$ & 3 \\
\hline & Explain the meaning of colloids & $\mathrm{C} 2$ & 4 \\
\hline & $\begin{array}{l}\text { Classify the types of colloids based on the } \\
\text { dispersed phase and dispersion medium along with } \\
\text { examples }\end{array}$ & $\mathrm{C} 3$ & 5 \\
\hline & $\begin{array}{l}\text { Classify colloidal samples based on the dispersed } \\
\text { phase and the dispersion medium }\end{array}$ & $\mathrm{C} 2, \mathrm{C} 4$ & 6,7 \\
\hline & $\begin{array}{l}\text { Determine the dispersed phase and dispersion } \\
\text { medium from a colloidal sample }\end{array}$ & $\mathrm{C} 3, \mathrm{C} 4$ & 8,9 \\
\hline \multirow{3}{*}{$\begin{array}{l}\text { Colloidal } \\
\text { Properties }\end{array}$} & Explain the properties of colloids (Tyndall effect, & & 10 \\
\hline & $\begin{array}{l}\text { Brownian motion, adsorption, electrophoresis, } \\
\text { dialysis, coagulation) }\end{array}$ & $\begin{array}{l}\mathrm{C} 2, \mathrm{C} 3 \\
\mathrm{C} 4\end{array}$ & $\begin{array}{l}11.12 \\
13,14 \\
15\end{array}$ \\
\hline & $\begin{array}{l}\text { Illustrate the properties of colloids (Brown motion, } \\
\text { Tyndall effect, adsorption, and electrophoresis) }\end{array}$ & $\mathrm{C} 3$ & $\begin{array}{c}16,17 \\
18\end{array}$ \\
\hline
\end{tabular}




\begin{tabular}{clcc}
\hline $\begin{array}{c}\text { Colloidal } \\
\text { Making }\end{array}$ & $\begin{array}{l}\text { Explain the difference between lyophilic colloids } \\
\text { and lyophobic colloids }\end{array}$ & C2 & 19,20 \\
\cline { 2 - 4 } & $\begin{array}{l}\text { Analyze the use of colloids in everyday life based } \\
\text { on their properties }\end{array}$ & C4 & $\begin{array}{c}21,22, \\
23\end{array}$ \\
\cline { 2 - 4 } & Explain how to make colloids & $\mathrm{C} 2$ & 24 \\
\hline $\begin{array}{l}\text { The Role of } \\
\text { Colloids in Daily }\end{array}$ & $\begin{array}{l}\text { Mention materials/substances in the form of } \\
\text { colloids in the pharmaceutical, cosmetic, food } \\
\text { ingredients, and others }\end{array}$ & $\mathrm{C} 1$ & 25 \\
\hline
\end{tabular}

\section{Research Data Analysis}

The results of the data are processed by statistical tests. Tests were carried out using the SPSS Version 21 for Windows program. There are three statistical tests used, namely normality test, Paired Sample T-Test and N-gain values.

The normality test is intended to determine whether the data from the pre-test \& post-test in measuring students' mastery of concepts are normally distributed or not. Normality test can be done by Kolmogorov-Smirnov test using SPSS Version 21 for Windows. The guidelines for making decisions on data that are normally distributed or not are as follows:

H0: Data is normally distributed

Ha: The data is not normally distributed

The basis for decision making for the normality test used the following criteria: If the value is significant $>0.05$ then $\mathrm{H} 0$ is accepted (normal data distribution). If the significant value $<0.05$ then $\mathrm{H} 0$ is rejected (data distribution is not normal). (Susetyo, 2010).

Paired Sample T-Test test aims to determine the significant difference between the two data if the data is normally distributed.

The hypotheses regarding the significance of the data are:

H0: There is no difference in the value of pretest and posttest

Ha: There is a difference in the value of pretest and posttest

The basis for decision making for the Paired Sample T-Test test used the following criteria:

If the significant value $<0.05$ then $\mathrm{Ha}$ is accepted (there is a difference)

If the significant value is $>0.05$, then $\mathrm{Ha}$ is rejected (no difference) (Susetyo, 2010).

The NGain score is used to see how far the students' mastery of concepts increases before and after learning. It is calculated based on the normalized gain value $(\mathrm{N}-$ gain) between the pretest and posttest scores. The calculation of N-gain is based on the following Hake (1998) equation: 


$$
g=\frac{\text { Spost }- \text { Spre }}{\text { Smaks }- \text { Spre }}
$$

Description: $\quad g$ :Normalized gain value (N-gain)

Spost : Postes Score

Spre : Pretest Score

Smax: Maximum score

The results of the $\mathrm{N}$-gain calculation are then translated according to the improvement criteria. The following are the criteria for increasing $\mathrm{N}$-gain:

Table 4. Criteria for Increasing $\mathrm{N}$-gain

\begin{tabular}{cl}
\hline $\mathbf{N}$-gain & Improvement Criteria \\
\hline $\mathrm{g}<0,3$ & Low upgrade \\
$0,3 \leq \mathrm{g} \leq 0,7$ & Moderate improvement \\
$\mathrm{g}>0,7$ & Height increase \\
\hline
\end{tabular}

(Hake, 1998)

\section{Research procedure}

The procedure of this research is that first a pretest is carried out to determine the initial ability of students. Furthermore, treatment is carried out by applying the RADEC learning model. The implementation of the RADEC learning model begins with students reading colloidal material through pre-learning assignments given by the teacher. This pre-learning task is done by students at home before students learn face-to-face. Pre-learning assignments contain colloidal materials that need to be mastered. The second stage is for students to answer pre-learning questions. This question is a question that requires students to think at a higher level. Then the third stage is discussion. At this stage, students actively discuss the material that has been studied and discuss the answers to pre-learning questions that have been done. Then the fourth stage is the stage of explaining. At this stage, students explain the material studied and discussed classically. At this stage, the teacher can explain colloidal material that is felt not yet mastered by students. The last stage of the RADEC learning model is the stage of making works. After the treatment, a post-test was conducted to determine the students' conceptual mastery ability after being given treatment.

\section{Results and Discussion}

\section{(1) Differences in Concept Mastery}

Differences in students' concept mastery can be analyzed from the results of the pretest and posttest data as follows: 


\section{a. Pretest Data Results}

The pretest activity was carried out before being given treatment. Based on the results of the study, data on the ability of students to master the concept of colloidal material based on the achievement of 13 learning indicators (maximum score of each indicator is 180) which can be seen in Figure 2.

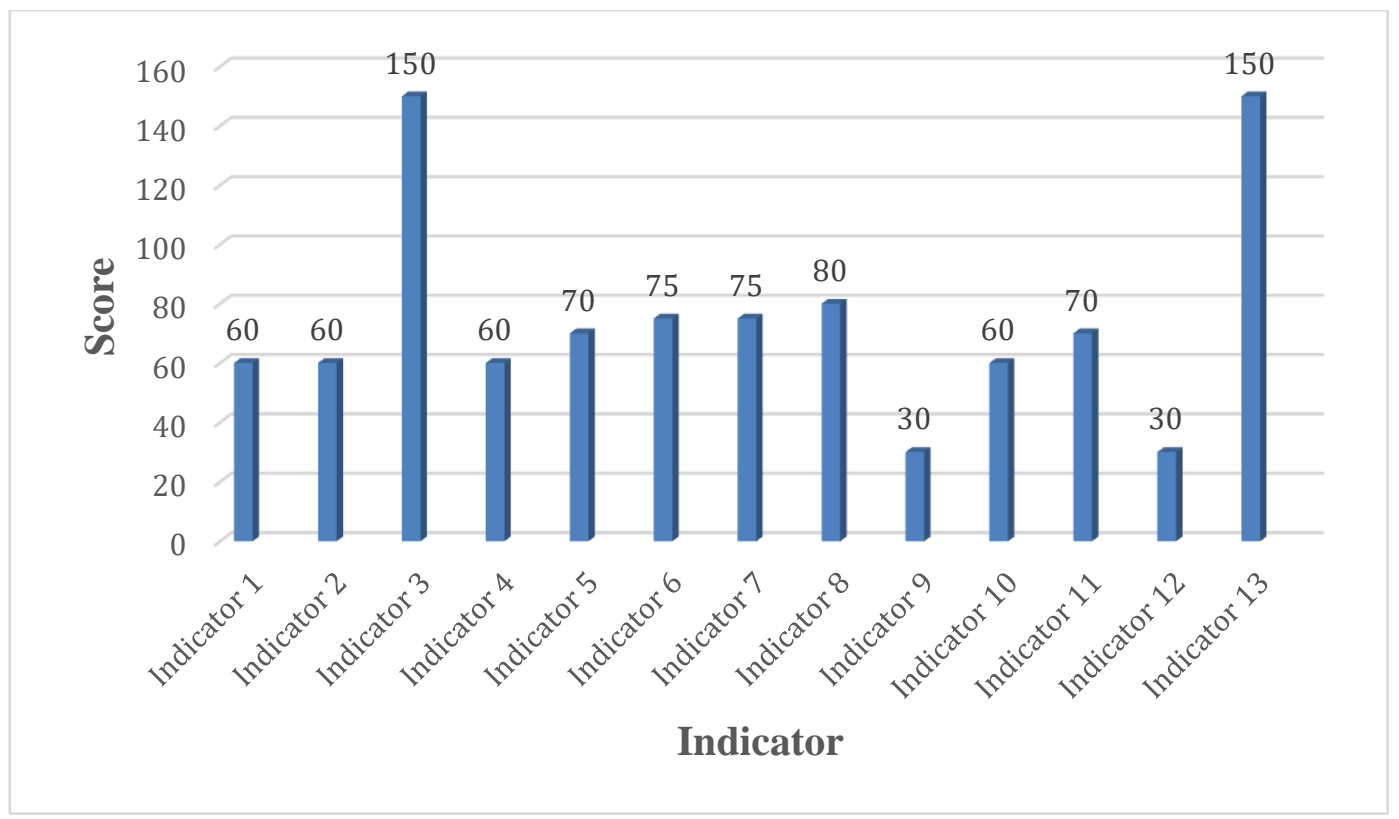

Figure 2. Results of the Pretest of Students' Concept Mastery

Figure 2 shows that in the pretest the indicators that have been mastered by students are indicator 3, namely grouping several mixtures into colloids, solutions, and suspensions and indicator 13 which mentions ingredients/substances in the form of colloids in industry, pharmaceuticals, cosmetics, food ingredients, and others -other. Meanwhile, indicators that are not mastered by students are indicator 9, which illustrates the nature of colloids and indicator 12, which is how to make colloids.

From the pretest data obtained, it can be interpreted that students are better able to answer questions whose indicators are related to procedural daily life compared to answering questions whose indicators are rote. This is based on the theory which states that students who develop mastery of concepts are faster in doing things related to procedural knowledge compared to students who memorize and remember only (Nisrina et al, 2017). The cognitive domain in indicator 3 groups some mixtures into colloids, solutions, and suspensions is C1 (Remembering) and indicator 13 mentions materials/substances in the form of colloids in industry, pharmaceuticals, cosmetics, foodstuffs, and others is C2 (Understanding) so that it is easier to be mastered by students compared to the cognitive domain, indicator 9 illustrates the nature of colloids and indicator 12 how to make colloids is C4 (Analyzing). 
The results of the analysis obtained that the overall initial ability of students' conceptual mastery on colloid material is included in the poor category. This is taken from the average score obtained by students, which is 39.7 .

b. Posttest Data Results

Mastery of students' concepts after being given learning using the RADEC model can be seen in Figure 3.

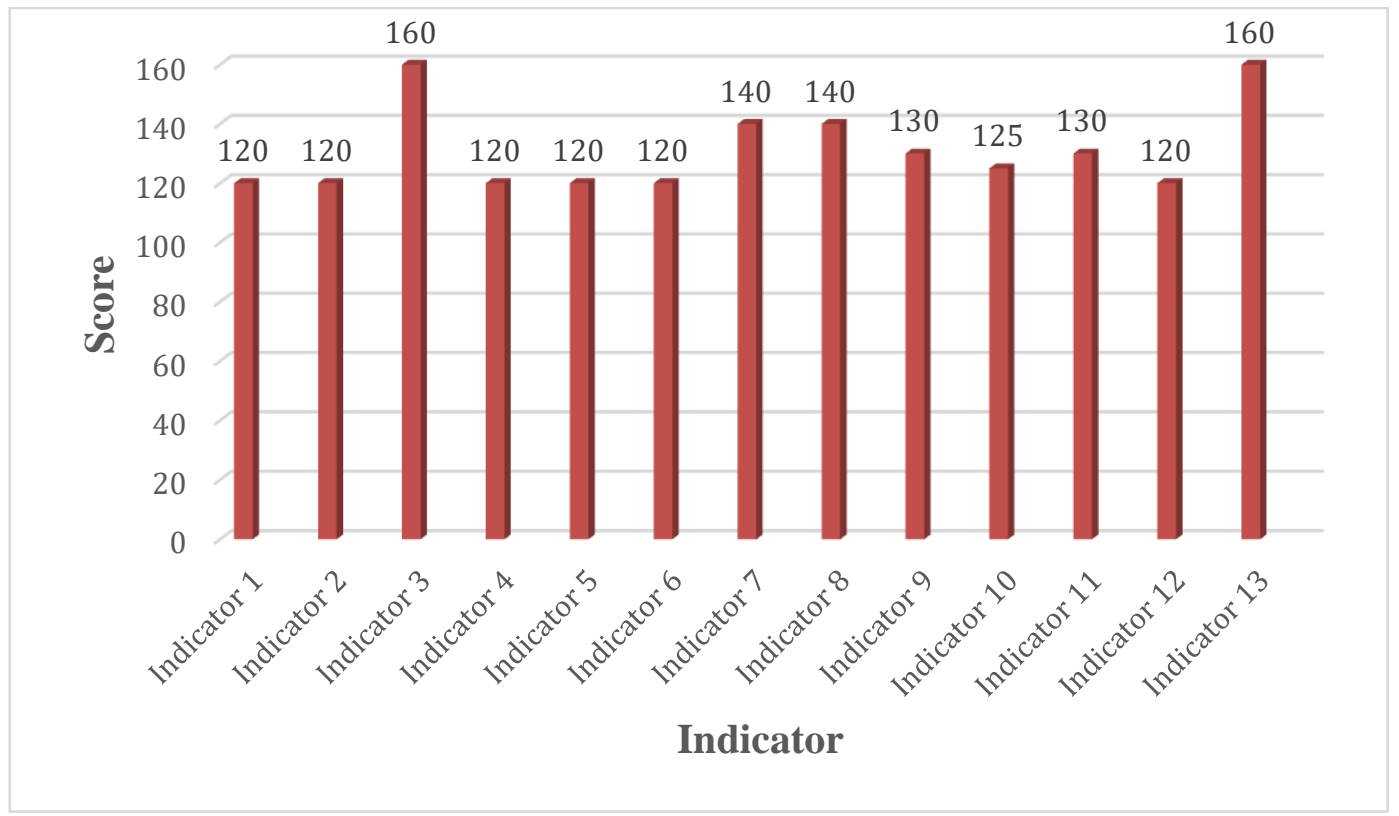

Figure 3. Results of Student Concept Mastery Posttest

Based on Figure 3, the results of the posttest of mastery of concepts on colloidal material are almost entirely controlled by students, this can be seen from the indicators that are entirely controlled by students. Based on the results of the overall analysis, the mastery of these students' concepts is included in the good category. This can be seen from the average posttest score obtained by students, which is 74.4 .

\section{(2) Improved Concept Mastery}

Mastery of the concept of students in general has increased significantly from each indicator. The description of the increase in students' conceptual mastery between before and after being given learning using the RADEC model is presented in Figure 4. 


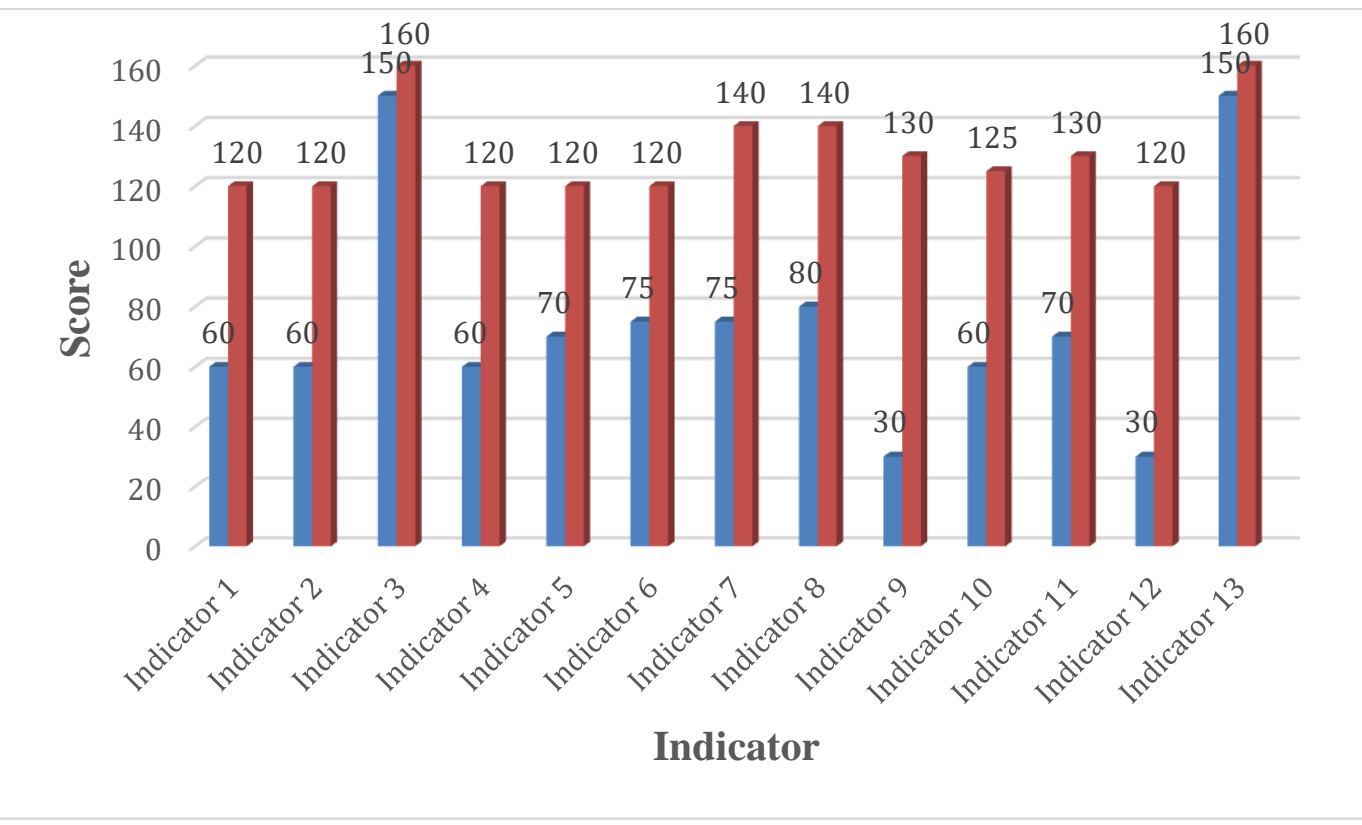

Figure 4. Increased Mastery of Students' Concepts

Figure 4 shows that the overall concept mastery ability of students has increased from each indicator and a moderate increase is obtained. In line with this explanation, to see the increase in mastery of concepts more clearly, the researcher presents a table of two different test means of pretest and posttest. The test data results were tested by statistical testing to test for normality, Paired Sample T-Test and N-gain values.

The results of statistical tests to test for normality are presented in table 5:

Table 5. Normality Test Results

\begin{tabular}{lrrr}
\hline & \multicolumn{3}{c}{ Kolmogorov-Smirnov $^{\mathrm{a}}$} \\
\cline { 2 - 4 } & df & & Sig. \\
\hline pretes & & 18 & .160 \\
\hline postes & & 18 & .006 \\
\hline & & Source: Results of data processing (2020)
\end{tabular}

From table 5 of the Kolmogorov-Smirnov normality test described above, it can be read that the significant value of pretest and posttest $>0.05$ so that the results of statistical data testing of students' pretest and posttest values are normal data with a significance value of 0.160 for pretest and 0.006 for posttest.

Paired Sample T-Test was used in this study because the data obtained were normal. Paired Sample T-Test is used to see the differences in students' mastery of concepts before and after learning is applied. The results of the comparison of the average mastery of students' concepts from the pretest and posttest are presented in table 6: 
Table 6. Results of Paired Sample T-Test

\begin{tabular}{lllcc}
\hline \multicolumn{1}{c}{ Jenis Tes } & $\mathrm{N}$ & Mean & $\begin{array}{c}\text { Std. } \\
\text { Deviation }\end{array}$ & T-test \\
\cline { 1 - 3 } Pretes & 18 & 39.77 & 13.264 & 0.000 \\
\cline { 1 - 3 } Postes & 18 & 74.44 & 16.471 & \\
\hline \multicolumn{4}{r}{ Source: Results of data processing (2021) }
\end{tabular}

Based on table 6, it can be seen that the significance value in the Paired Sample TTest is $0.000<0.005$, then $\mathrm{H} 0$ is rejected and $\mathrm{Ha}$ is accepted, it means that there is a difference in the average mastery of students' concepts before and after learning is applied.

$\mathrm{N}$-gain is used to see how much the students' mastery of concepts increases. The results of the $\mathrm{N}$-gain statistical test can be seen in table 7:

Table 7. Results of N-gain

\begin{tabular}{cccccc}
\hline $\begin{array}{c}\text { Number of } \\
\text { Respondents }\end{array}$ & $\begin{array}{c}\text { Total } \\
\text { Pretest } \\
\text { Score }\end{array}$ & $\begin{array}{c}\text { Total } \\
\text { Posttest } \\
\text { Score }\end{array}$ & $\begin{array}{c}\text { Total } \\
\text { Posttest } \\
\text { Score - Total } \\
\text { Pretest Score }\end{array}$ & $\begin{array}{c}\text { Maximum } \\
\text { Total Score - } \\
\text { Total Pretest } \\
\text { Score }\end{array}$ & N-Gain \\
\hline 18 & 39.7 & 74.4 & 34.6 & 60.2 & 0.56 \\
\hline
\end{tabular}

From table 7 the $\mathrm{N}$-gain results obtained are 0.56 . The results of the $\mathrm{N}$-gain calculation are then translated according to the criteria for improvement according to Hake (1998), which is a moderate increase. Thus it can be concluded that there is a difference and a moderate increase in students' conceptual mastery between before and after being given treatment using the RADEC learning model on colloidal material. The increasing mastery of students' concepts is due to the steps of the RADEC model that encourage students to master the material being studied so that students gain a high understanding (Sopandi, 2017; Handayani \& Sopandi, 2019).

\section{Conclusion}

Based on the results of the study, it was stated that there were differences in students' concept mastery before and after the learning was applied and there was an increase in the moderate category of students' concept mastery through RADEC learning. This means that the stages of the RADEC learning model are effective in increasing students' mastery of concepts on colloidal material. The RADEC learning model has implications for the learning process, namely it can encourage students to be more active in the learning process, develop the ability to explain students, train students to work together, and improve students' reading habits. 


\section{Acknowledgment}

The author would like to thank Dr. Paed. Wahyu Sopandi, M.A and Dr. Momo Rosbiono, M.Sc., M.Pd who has provided guidance for this research. The author would also like to thank the chemistry teacher, as well as the MIA XI-2 class students who have helped the researcher in conducting the research.

\section{References}

Anderson, L.W., \& Krathwohl, D.R. (2001). A Taxonomy for Learning, Teaching and Assesing: A Revision of Bloom's Taxonomy of Educatioanl Objectives. New York: Addison Wesley Longman, Inc.

Bloom, S. E. (1974). Current knowledge about the avian W chromosome. BioScience, 24(6), 340-344. https://doi.org/10.2307/1296739.

Carroll, J. B. (1963). A model of school learning. Teachers college record. Retrieved from http://garfield.library.upenn.edu/classics1982/A1982NF37300001.pdf

Hake, R.R. (1998). Analyzing Change/Gain Scores. USA: Indiana University.

Handayani, H., Sopandi, W., Syaodih, E., Setiawan, D., \& Suhendra, I. (2019). Dampak perlakuan model pembelajaran RADEC bagi calon guru terhadap kemampuan merencanakan pembelajaran di sekolah dasar. Pendas: Jurnal Ilmiah Pendidikan Dasar, 4(1), 79-93.

Heer, R. (2012). A Model of Learning Objectives based on A Taxonomy for Learning, Teaching, and Assessing: A Revision of Bloom's Taxonomy of Educational Objectives. Center for Excellence in Learning and Teaching, Iowa State University.

Krathwohl, D. R. (2002). A revision of Bloom's taxonomy: An overview. Theory into practice, $41(4), 212-218$.

Latisma, dkk. (2015). Analisis Kecenderungan Pemahaman Konsep Siswa Ditinjau Dari Gaya Belajar Pada Materi Sistem Koloid Di SMA Kerinci. Prosiding Semirata MIPA Universitas Tanjungpura, Pontianak 523 - 532.

Nisrina, N., Gunawan, G., \& Harjono, A. (2016). Pembelajaran Kooperatif dengan Media Virtual untuk Peningkatan Penguasaan Konsep Fluida Statis Siswa. Jurnal Pendidikan Fisika dan Teknologi, 2(2), 66-72.

Ritonga, I. (2019). Skripsi: Pengaruh Gender Terhadap Peningkatan Kemampuan Aktual Siswa Pada Materi Koloid. Bandung: Universitas Pendidikan Indonesia.

Setiawan, D., Sopandi, W., \& Hartati, T. (2019). Kemampuan menulis teks eksplanasi dan penguasaan konsep siswa sekolah dasar melalui implementasi model pembelajaran RADEC. Premiere Educandum Jurnal Pendidikan Dasar dan Pembelajaran, 9(2), 130-140.

Setiawan, D., Hartati, T., \& Sopandi, W. (2020). Effectiveness Of Critical Multiliteration Model With Radec Model On The Ability Of Writing Explanatory Text. Edu Humaniora Jurnal Pendidikan Dasar Kampus Cibiru, 12(1), 1-14. 
Silaban, B. 2014. Hubungan Amtara Penguasaan Konsep Fisika dan Kreativitas dengan Kemampuan Memecahkan Masalah pada Materi Pokok Listrik Statistik. Jurnal Penelitian Bidang Pendidikan. Vol 20 (1).65-75.

Siregar, L. S. (2019). Tesis: Desain Pembelajaran Polimer Menggunakan Model Read-Answer-Discuss-Explain-Create (RADEC) Berbasis Google Classroom untuk Mengembangkan Penguasaan Konsep dan Kreativitas Siswa SMK pada Pembuatan Bioplastik. Bandung: Universitas Pendidikan Indonesia.

Sopandi, W. (2017). The quality improvement of learning processes and achievements through the read-answer-discuss-explain-and create learning model implementation. Proceeding 8th Pedagogy International Seminar 2017: Enhancement of Pedagogy in Cultural Diversity Toward Excellence in Education, 8(229), 132-139.

Sopandi, W. (2019). Sosialisasi dan Workshop Implementasi Model Pembelajaran RADEC Bagi Guru-Guru Pendidikan Dasar dan Menengah [Dissemination and Implementation Workshop of RADEC Learning Models for Primary and Secondary Education Teachers]. Pedagogia: Jurnal Pendidikan, 8(1), 19-34.

Suranti, N. M. Y., Gunawan, G., \& Sahidu, H. (2016). Pengaruh Model Project Based Learning Berbantuan Media Virtual Terhadap Penguasaan Konsep Peserta didik pada Materi Alat-alat Optik. Jurnal Pendidikan Fisika dan Teknologi, 2(2), 73-79.

Susetyo, B. (2010). Statistika Analisis Data Penelitian. Bandung: refika Aditama.

Suwarto. (2010). Dimensi Pengetahuan dan Dimensi Proses Kognitif dalam Pendidikan. Journal Widyatama. 19 (1): 76 - 91.

Thorndike, R. L. (1976). Reading comprehension education in fifteen countries: International Studies in Evaluation. New York: Wiley. https://doi.org/10.1086/445874.

Vellanda, S. (2019). Skripsi: Penguasaan Materi Kesetimbangan Kimia Melalui Implementasi Model Pembelajaran Read-Answer-Discuss-Explain And Create (RADEC). Bandung: Universitas Pendidikan Indonesia.

Vygotsky, L. S. (1978). Mind in society: The Development of Higher Psychological Processes (M. Cole, V John-Steiner, S. Scribner, \& E. Souberman, Eds.). Cambridge, MA: Harvard University Press.

Wiersma, W. \& Jurs, S.G. (2009). Research Methods in Education an Introduction. US: Pearson Education, Inc.

How to cite this article:

Ritonga, R. A., Sopandi, W., \& Rosbiono, M. (2021). Student Concept Mastery on Coloid Material Through Radec Learning. Journal of Educational Sciences, 5(3), 520-532. 